Article

\title{
Toxicity of Piperine Amide Analogs toward the Tomato Pinworm Tuta absoluta (Lepidoptera: Gelechiidae) and Risk Assessment for Two Predators
}

\author{
Elba Pereira ${ }^{1}$, Elizeu Farias ${ }^{2, *}{ }^{\oplus}$, Arthur Ribeiro ${ }^{2}$, Elson Alvarenga ${ }^{3}$, Alex Aguiar ${ }^{3}$, \\ Jhulyana Ferreira $^{2}$ and Marcelo Picanço ${ }^{2}$ \\ 1 Laboratório de Pesticidas, Laboratório Nacional Agropecuário em Minas Gerais - LANAGRO, Pedro \\ Leopoldo, MG 33600-000, Brazil; elbancp@yahoo.com.br \\ 2 Departamento de Entomologia, Universidade Federal de Viçosa, Viçosa, MG 36570-900, Brazil; \\ arthurvieira3@gmail.com (A.R.); jhulyana.mip@gmail.com (J.F.); picanco@ufv.br (M.P.) \\ 3 Departamento de Química, Universidade Federal de Viçosa, Viçosa, MG 36570-900, Brazil; \\ elson@ufv.br (E.A.); alex.aguiar@ufv.br (A.A.) \\ * Correspondence: elizeusf21@gmail.com
}

Received: 27 August 2019; Accepted: 29 September 2019; Published: 5 October 2019

\begin{abstract}
Nineteen amides (three of them unpublished) were synthesized and tested on Tuta absoluta Meyrick (Lepidoptera: Gelechiidae), an important pest of Solanaceae plants worldwide. Three of these compounds $\left(14,15\right.$ and 16) presented high acute toxicity toward the pest, with $L_{50} \mathrm{~s}$ of 3.68 $\left(\mathrm{CI}_{95}=2.83-4.47\right), 6.46\left(\mathrm{CI}_{95}=5.85-7.20\right)$, and $13.52 \mu \mathrm{g} / \mathrm{mg}\left(\mathrm{CI}_{95}=11.06-15.95\right)$, respectively. Amide 14 presented the fastest action $\left(\mathrm{LT}_{50}=1.2\right.$ minutes, $\left.\mathrm{CI}_{95}=1.03-1.37\right)$, followed by amide $16\left(\mathrm{LT}_{50}=18\right.$ minutes, $\left.\mathrm{CI}_{95}=9.96-26.04\right)$, and amide $15\left(\mathrm{LT}_{50}=3.7\right.$ hours, $\left.\mathrm{CI}_{95}=0.69-6.71\right)$. When applied at a sublethal dose, they did not affect weight gain and leaf consumption of the pest. Bioassays were also conducted using the ant Solenopsis saevissima (Hymenoptera: Formicidae) and wasp Polybia ignobilis (Hymenoptera: Vespidae) to assess the toxicity of the amides against T. absoluta predators. Amides 14, 15, and 16 were harmless to $S$. saevissima but presented high toxicity toward $P$. ignobilis. Amides 14, 15 and 16 are potential hit compounds for the development of insecticides for T. absoluta control. However, their use should be carried out following the principles of ecological selectivity to mitigate potential adverse effects on non-target organisms.
\end{abstract}

Keywords: invasive pest; natural-based insecticide; tomato

\section{Introduction}

The tomato pinworm Tuta absoluta Meyrick (Lepidoptera: Gelechiidae) is an important pest of Solanaceae [1,2]. Native to South America, this pest was introduced into Europe in the last decade and currently can be found throughout Europe, Africa, and Asia [3-7]. The damage of this pest is greater in tomato crops (Solanum lycopersicum L.), where its larvae build galleries in leaves and burrow into fruits and branches [8]. Thus, crop yield and fruit marketability are compromised [9].

Alternatives such as cultural and biological controls have been sought for the management of T. absoluta, but the use of insecticide remains the primary control measure used by tomato growers, especially in South America [2]. Continuous application of insecticides contributes to the development of T. absoluta-resistant strains, which reduces the efficacy of several products registered to control this pest [10-15]. Another problem related to the use of insecticides are the side-effects of some molecules on non-target organisms, such as predators, pollinators, and detritivore arthropods [16-18].

In this sense, studies related to the development of new insecticidal molecules are important, aiming at the discovery and synthesis of active compounds against pests and less harmful to the 
environment [19]. Natural products have been consistently used as models in the synthesis of new insecticides [20]. Pyrethroids and neonicotinoids are examples of synthetic insecticides based on molecules extracted from plants [21]. Piperine is an amide found in fruits of Piperaceae plants with insecticidal activity against several pests [22,23], and has been used as a model for the synthesis of analogous products [24-26].

Given the demand for the development of new insecticidal molecules for T. absoluta management, this study evaluated the potential of 19 piperine analogs as hit compounds for the development of insecticides against this pest.

\section{Materials and Methods}

\subsection{Synthesis}

(2E,4E)-Hexa-2,4-dienoic acid (sorbic acid), a diene with six carbon atoms, presents the right functional group for amide formation and is readily available for the preparation of piperine analogs. The precursor acid chloride was prepared by treatment of sorbic acid with oxalyl chloride. Amides with conjugated double bonds were prepared by the reaction of hexa-2,4-dienoyl chloride with the corresponding amines [27]. The amides were characterized as (2E,4E)-N-cyclohexylhexa-2,4-dienamide (1), (2E,4E)-N-benzylhexa-2,4-dienamide (2), (2E,4E)-N-phenethylhexa-2,4-dienamide (3), (2E,4E)-N-phenylhexa-2,4-dienamide (4), (2E,4E)-N,N-diphenylhexa-2,4-dienamide (5), (2E,4E)-N,N-di(propan-2-yl)hexa-2,4-dienamide (6), (2E,4E)-N, $N$-(diethyl)hexa-2,4-dienamide (7), (2E,4E)-1-(pyrrolidin-1-yl)hexa-2,4-dien-1-one (8), (2E,4E)-N-hexylhexa-2,4-dienamide (9), and (2E,4E)-1-(piperidin-1-yl)hexa-2,4-dien-1-one (10).

To compare the insecticidal activity of amides with conjugated double bonds, nine saturated amides were synthesized by the reaction of hexanoic anhydride with the corresponding amine. The products were characterized as $N$-phenylhexanamide (11), $N$-benzylhexanamide (12), N-cyclohexylhexanamide (13), 1-(pyrrolidin-1-yl)hexan-1-one (14), N-pentylhexanamide (15), $\mathrm{N}$-phenethylhexanamide (16), $\mathrm{N}$-(4-nitrophenyl)hexanamide (17), $\mathrm{N}$-(4-chlorophenyl)hexanamide (18), and $\mathrm{N}$-(3-chlorophenyl)hexanamide (19). To our knowledge, this is the first study to report the synthesis of amides 3, 9, and 19. Chemical structures of the evaluated amides and the details of the experimental procedures and physical and spectroscopic data (IR, ${ }^{1} \mathrm{H} N \mathrm{NM},{ }^{13} \mathrm{C} N \mathrm{NR}$, and MS) used for the complete structural characterization of the new compounds are provided in the supplementary material.

\subsection{Insecticidal Bioassays}

\subsubsection{Amide's Susceptibility Bioassay}

Bioassays were performed with second instar larvae of T. absoluta. The population used has been maintained in the laboratory for more than ten years [28]. Larvae were fed tomato leaves (Solanum lycopersicon L. var. Santa Clara) from plants cultivated under greenhouse conditions without any insecticide application. The treatments were the 19 amides, piperine (positive control), and acetone (negative control). Piperine was used as the positive control due to its reported insecticidal action against lepidopteran pests, in addition to its structural similarity with the synthesized compounds [22,24]. The compounds were diluted in acetone at a dose of $30 \mu \mathrm{g} / \mathrm{mg}$ of body weight and topically applied at the dorsal thorax $(0.5 \mu \mathrm{L}$ per insect) using a Hamilton microsyringe. This dose was adopted based on previous studies that recommend doses from 10 to $50 \mu \mathrm{g} / \mathrm{mg}$ of body weight to select substances with insecticidal activity [29,30]. The experimental unit was a plastic pot $(6 \mathrm{~cm}$ diameter $\times 5 \mathrm{~cm}$ height) containing ten T. absoluta larvae. The design was completely randomized with three replicates. Mortality was evaluated after a 48 -h exposure to the treatments. Insects were considered dead when they did not move when touched by a fine brush. Mortality data were checked for normality (Shapiro-Wilk test) and for homoscedasticity of residuals (Bartlett test), and subjected to ANOVA, followed by the Scott-Knott cluster analysis at $P=0.05$ [31,32]. Amides causing mortality rates $\geq 80 \%$ to 
T. absoluta larvae were selected for the subsequent bioassays since this is the minimum value required by Brazilian legislation to select potential insecticidal molecules [33].

\subsubsection{Dose-Response Bioassay}

The same procedures of the previous bioassay were used. The treatments were the most efficacious amides (selected in the previous bioassay) applied at different doses, piperine, and acetone control. Five to six doses causing mortalities between $1 \%$ and $99 \%$ were used for each treatment. Mortality data were subjected to probit analysis (PROC PROBIT, SAS 9.2, SAS Institute Inc, Cary, NC, USA) to estimate the dose-mortality curves. Lethal doses $\left(\mathrm{LD}_{25}, \mathrm{LD}_{50}\right.$, and $\left.\mathrm{LD}_{80}\right)$ and their respective confidence intervals $\left(\mathrm{CI}_{95}\right)$ for the most efficacious amides were estimated by regression analysis of probit mortality to T. absoluta larvae versus $\log 10$ of dose. The goodness-of-fit was assessed using Pearson's chi-square test. $P$-values $>0.05$ of Pearson's chi-square test indicated a significant fit between the observed and expected regression models. Estimates of the lethal doses were significantly different when their $\mathrm{CI}_{95}$ did not overlap.

\subsubsection{Time-Response Bioassay}

In order to estimate the speed of action of the most efficacious amides, 100 second instar larvae of $T$. absoluta were treated with the $\mathrm{LD}_{90}$ of the treatments (amides and piperine). The death of the larvae was monitored for $48 \mathrm{~h}$ by noting the time at which each insect died. The mortality was assessed manually every 10 min during the first hour of the experiment, every $1 \mathrm{~h}$ up to $24 \mathrm{~h}$ and subsequently, every $4 \mathrm{~h}$ up to $48 \mathrm{~h}$. Insects were considered dead when they did not move when touched by a fine brush. Experimental data were subjected to survival analysis using Kaplan-Meier estimators (PROC LIFETEST, SAS 9.2) to obtain survival curves and estimates of median lethal times $\left(\mathrm{LT}_{50} \mathrm{~s}\right)$. Overall similarity among the survival curves and $\mathrm{LT}_{50} \mathrm{~S}$ values was tested using the Log-Rank test, and pairwise comparisons among the curves were tested using the Holm-Sidak's test at $P=0.05$.

\subsubsection{Sublethal Effects on Weight Gain and Leaf Consumption}

Sublethal effects of the most efficacious amides to T. absoluta were investigated using second instar larvae treated with the $\mathrm{LD}_{25}$ for the pest. The larvae were weighed individually and treated by topical application. The control consisted of the application of acetone. The larvae ( 25 per treatment) were individualized in plastic pots $(6 \mathrm{~cm}$ diameter $\times 5 \mathrm{~cm}$ height $)$ and fed tomato leaflets. After $96 \mathrm{~h}$, the leaflets were photographed using an EOS Digital Rebel XS camera (Canon Inc., Taiwan, China) and the larvae were removed from the mines and weighed. Leaf area consumed was calculated using the software ImageJ (version 1.50i; National Institutes of Health, Bethesda, MD, USA). Data of weight increment of the larvae $(\mathrm{mg})$ and leaf area consumed $\left(\mathrm{cm}^{2}\right)$ were subjected to ANOVA (PROC GLM, SAS 9.2) at $P=0.05$.

\subsubsection{Risk Assessment for T. absoluta Predators}

Adults of Solenopsis saevissima Smith (Hymenoptera: Formicidae) and Polybia ignobilis Haliday (Hymenoptera: Vespidae) were exposed to the most efficacious amides $\left(\mathrm{LD}_{80}\right.$ for T. absoluta) in order to assess the toxicity of the amides toward T. absoluta predators. They were collected from nests located at the Universidade Federal de Viçosa campus and kept in the laboratory to acclimatize for at least two hours before the bioassays. The experimental units comprised either a round plastic container $(6 \mathrm{~cm}$ diameter $\times 5 \mathrm{~cm}$ height) or a Petri dish $(9 \mathrm{~cm}$ diameter $\times 2 \mathrm{~cm}$ height) containing ten insects for S. saevissima and P. ignobilis, respectively. The experiment was performed with six replicates. The wasps were immobilized by placing them in a freezer at $-18^{\circ} \mathrm{C}$ for 4 minutes. After the application, the insects were kept in an acclimatized room at $25 \pm 0.5^{\circ} \mathrm{C}$ and $75 \pm 5 \%$ relative humidity. Polybia ignobilis was subjected to a photoperiod of $12 \mathrm{~h}$ while $S$. saevissima was kept in the dark during the bioassay. Mortality data were subjected to ANOVA, followed by the Tukey's test at $P=0.05$ (PROC TTEST, SAS 9.2). 


\section{Results}

\subsection{Amide Susceptibility Bioassay}

There was a significant effect of the treatments in the mortality of T. absoluta larvae (ANOVA: $\mathrm{F}_{20,42}=33.48, P<0.001$ ). Amides 14 and 15 and the positive control (piperine) caused the highest mortality rates (>95\%). Amide 16 caused $78 \%$ mortality to T. absoluta, a value not statistically different from $80 \%$ (One sample $t$-test: $t=-0.275, P=0.81$ ), the minimum mortality rate required by Brazilian legislation to select potential insecticidal molecules. The other tested amides caused low mortalities $(<45 \%)$ (Figure 1).

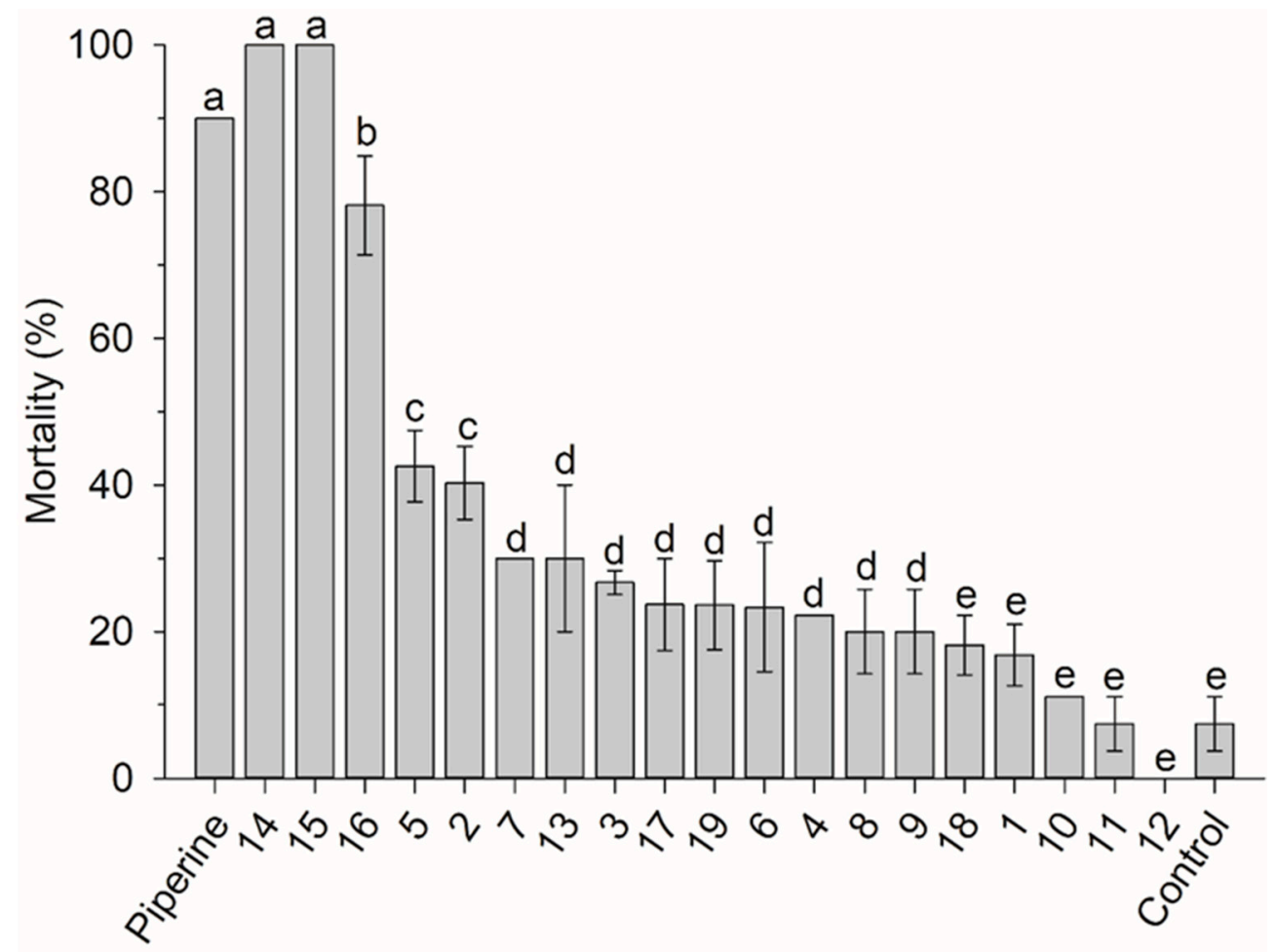

Figure 1. Mortality (\%) of Tuta absoluta larvae $48 \mathrm{~h}$ after topical application of 19 amides and piperine at the dose of $30 \mu \mathrm{g} / \mathrm{mg}$ of body weight. Different letters above bars indicate significant differences in mean mortalities according to ANOVA and Scott-Knott test $(P<0.05)$. Control $=$ acetone.

\subsection{Dose-Response Bioassay}

Pearson's Chi-square test statistic (all values of $P>0.05$ ) indicated that the data fitted the regression models. The lethal doses of the amides against T. absoluta are shown in Table 1. Amide $14\left(\mathrm{LD}_{50}=3.68\right.$ $\left.\mu \mathrm{g} / \mathrm{mg}, \mathrm{CI}_{95}=2.83-4.47\right)$ was as toxic as piperine $\left(\mathrm{LD}_{50}=3.80 \mu \mathrm{g} / \mathrm{mg}, \mathrm{CI}_{95}=2.92-4.81\right)$. The $\mathrm{LD}_{50}$ of amides 15 and 16 were $6.46\left(\mathrm{CI}_{95}=5.85-7.20\right)$ and $13.52 \mu \mathrm{g} / \mathrm{mg}\left(\mathrm{CI}_{95}=11.06-15.95\right)$, respectively.

Table 1. Dose-mortality curves of the most efficacious amides and piperine (positive control) to second instar larvae of Tuta absoluta 48 hours after topical application.

\begin{tabular}{cccccc}
\hline Compound & $\mathbf{N}^{\mathbf{a}}$ & Slope $^{\mathbf{b}}$ & LD $_{\mathbf{5 0}}(\boldsymbol{\mu g} / \mathbf{m g})^{\mathbf{b}}$ & Chi-square $^{\mathbf{d}}$ & P-Value $^{\mathbf{d}}$ \\
\hline Amide 14 & 240 & $3.14(2.29-3.99)$ & $3.68(2.83-4.47)$ & 0.22 & 0.90 \\
Amide 15 & 300 & $5.29(3.82-6.76)$ & $6.46(5.85-7.20)$ & 1.82 & 0.61 \\
Amide 16 $^{4}$ & 420 & $2.47(1.96-2.98)$ & $13.52(11.06-15.95)$ & 3.34 & 0.65 \\
Piperine $^{\mathrm{c}}$ & 300 & $1.79(1.38-2.20)$ & $3.80(2.92-4.81)$ & 0.11 & 0.99 \\
\hline
\end{tabular}

\footnotetext{
a Number of insects; ${ }^{\mathrm{b}}$ The numbers in parenthesis are the confidence intervals at $P=0.05$ (CI95); ${ }^{\mathrm{c}}$ Positive control; d Pearson's chi-square: $P$-values $>0.05$ indicate that the observed regression model is not significantly different from the expected model.
} 


\subsection{Time-Response Bioassay}

Survival analysis of T. absoluta larvae exposed to the control and the amides indicated a significant difference between the treatments (log-rank test: $\chi^{2}=303.46$, d.f. $=3, P<0.001$ ). Survival curves for all treatments differed by the Holm-Sidak method $(P<0.05)$. Amide 14 presented the fastest action $\left(\mathrm{LT}_{50}\right.$ $=1.2$ minutes, $\left.\mathrm{CI}_{95}=1.03-1.37\right)$, followed by amide $16\left(\mathrm{LT}_{50}=18\right.$ minutes, $\left.\mathrm{CI}_{95}=9.96-26.04\right)$ and amide $15\left(\mathrm{LT}_{50}=3.7\right.$ hours, $\left.\mathrm{CI}_{95}=0.69-6.71\right)$ (Figure 2).

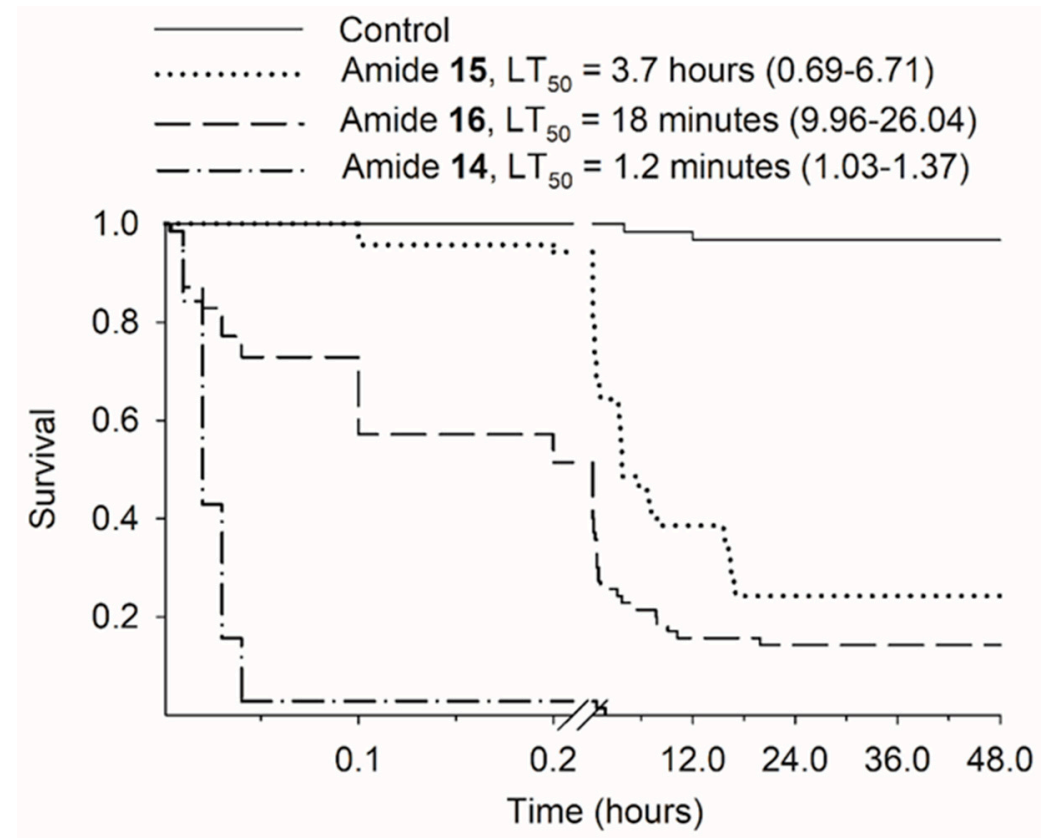

Figure 2. Survival curves of Tuta absoluta larvae topically treated with the $\mathrm{LD}_{90}$ of the amides 14, 15, and 16. Control = acetone.

\subsection{Sublethal Effects on Weight Gain and Leaf Consumption}

Weight gain $\left(\mathrm{F}_{3,76}=1.23, P=0.31\right)$ and leaf consumption $\left(\mathrm{F}_{3,99}=0.54, P=0.66\right)$ of Tuta absoluta larvae were not affected by the $\mathrm{LD}_{25}$ of amides 14,15 , and 16 (Figure 3).
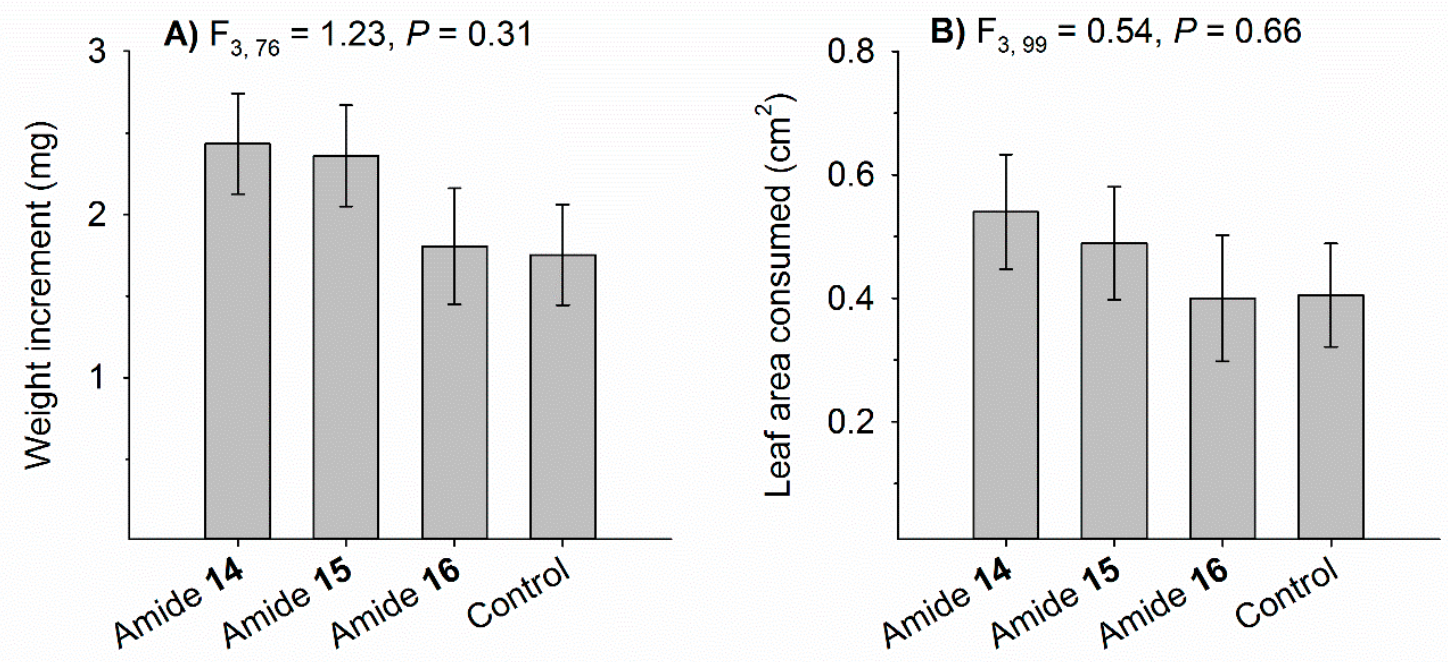

Figure 3. Weight increment (A) and leaf area consumed (B) by Tuta absoluta larvae topically treated with the $\mathrm{LD}_{25}$ of amides 14,15 , and 16. Control = acetone. 


\subsection{Risk Assessment for T. absoluta Predators}

Amides 14, 15, and 16 caused low mortality rates $(<8 \%)$ to $S$. saevissima. Conversely, they were highly toxic (mortality $>93 \%$ ) toward P. ignobilis (Figure 4 ).

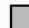

S. saevissima

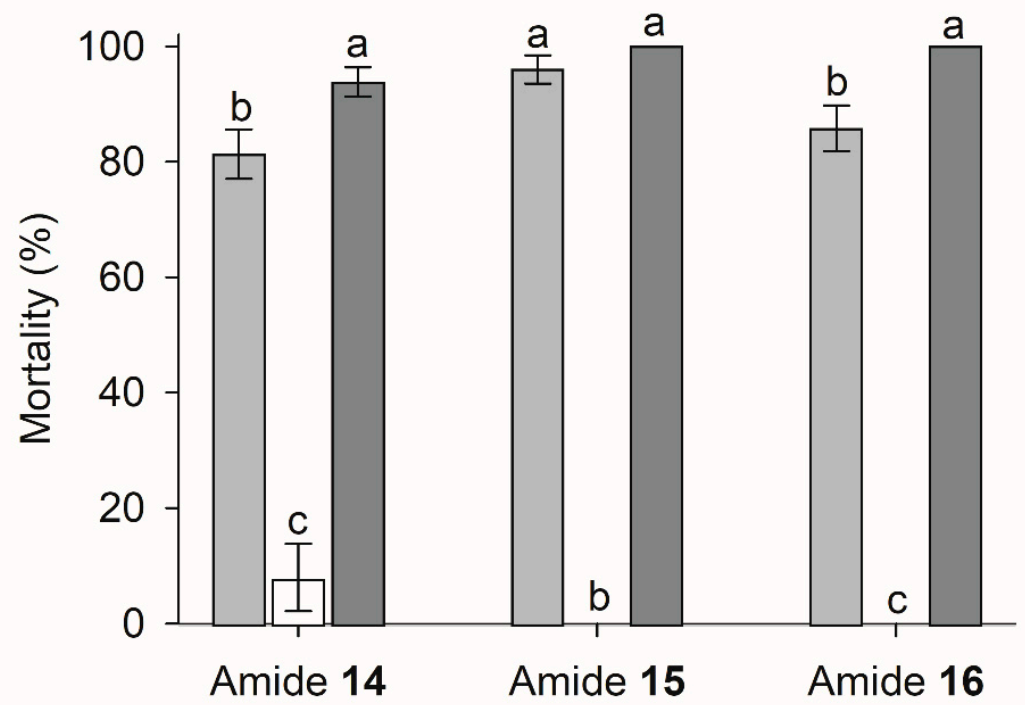

Figure 4. Mortality (\%) caused by $\mathrm{LD}_{80}$ of amides 14,15 , and 16 to Tuta absoluta larvae and the predators Solenopsis saevissima and Polybia ignobilis, 48 hours after topical exposure. Means followed by the same letter in each column group (amide) do not differ by Tukey's test $(P<0.05)$.

\section{Discussion}

The most efficacious compounds $(\mathbf{1 4}, \mathbf{1 5}$, and 16) are illustrated in Figure 5. They are structurally similar to amides $\mathbf{8}, \mathbf{9}$, and $\mathbf{3}$, respectively, differing mainly in relation to the absence of double bonds in carbons 2 and 4 of the main chain (Supporting material, Schemes S1 and S2). This fact indicates that saturation may be related to the higher insecticidal activity of the molecules against this pest. In addition, the most efficacious amides and four more of the tested amides have the same main chain, evidencing that the constitution of the side chain is also important for the biological activity of these molecules.

The similar $\mathrm{LD}_{50}$ of the amide $\mathbf{1 4}$ and piperine indicates that the former is a promising substance for use in the control of T. absoluta since piperine is a botanical insecticide recommended for the control of insect pests [34,35]. The two most toxic amides (14 and 15) had the highest curve slopes. Steep slopes in dose mortality-curves indicated, for the same increase in mortality, less proportional increment in dose, increasing the chance of application error [36]. However, this does not exclude the potential of these compounds for use as insecticides, since formulations can increase their efficiency and stability [37]. Amides have been shown to be efficient in controlling insecticide-resistant pest populations [34,38], as well as acting synergistically with other pesticides $[39,40]$. Thus, insecticide mixtures containing the amides and other active ingredients can be developed for T. absoluta control, contributing to the management of insecticide resistance. 


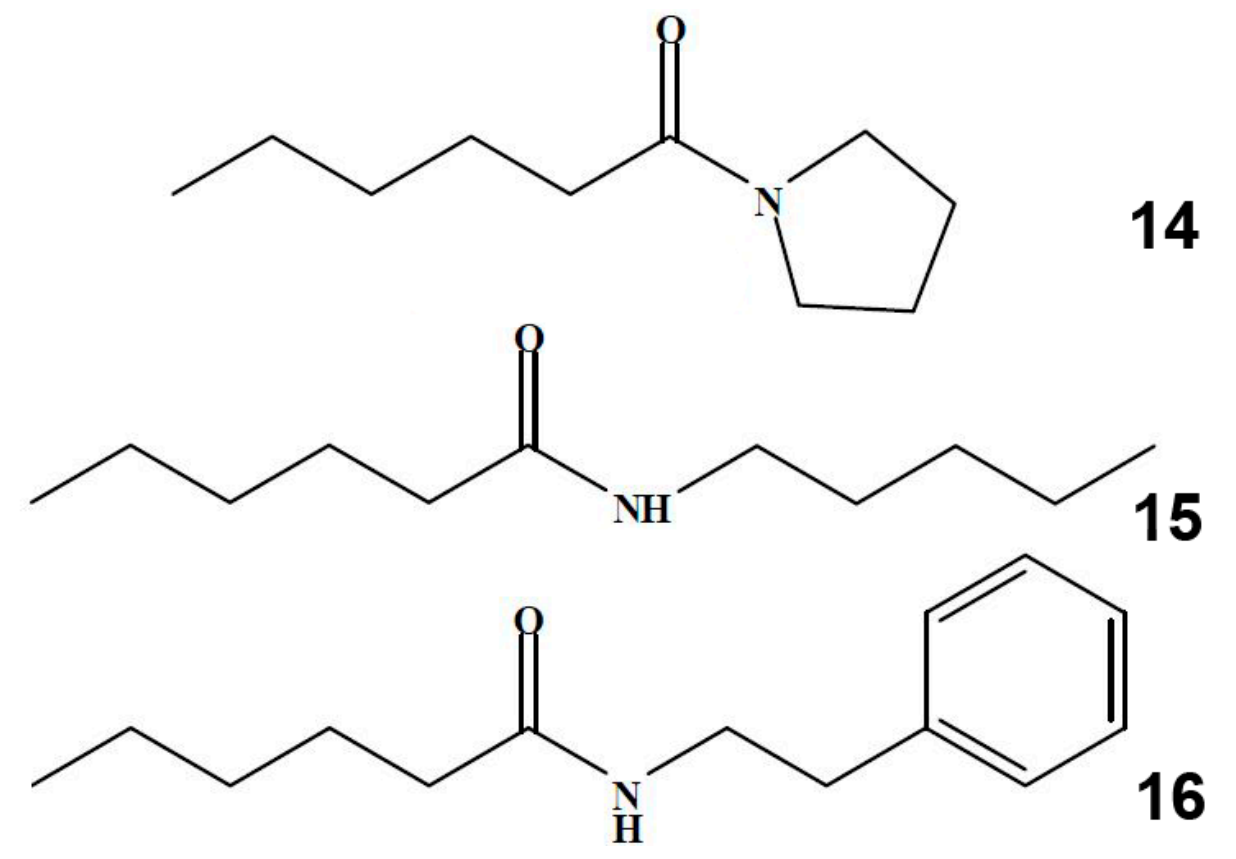

Figure 5. Structures of the most active compounds.

The fast action against T. absoluta is important, especially during the reproductive phase of tomato plants, reducing the damage caused by this insect to fruit [28]. In addition, the fast insecticidal activity of amides 14, 15, and 16 is indicative of the neurotoxic action of these substances. This hypothesis is reinforced by the fact that neurotoxic action, in addition to inhibition of detoxifying enzymes, was pointed out as the mode of action of other amides [34,41]. Further studies aiming to elucidate the mode of action of these substances should be performed.

Insect exposure to sublethal doses is common in the field due to the degradation of insecticides by environmental conditions [42,43]. Sublethal doses of insecticides can reduce biological parameters of insects $[44,45]$. On the other hand, undesirable effects can also occur, such as increased consumption, oviposition, and survival, which favors the emergence of resistant insects [44,46]. Here, amides 14, 15, and $\mathbf{1 6}$ in a sublethal dose did not affect the weight gain and leaf consumption of T. absoluta larvae, indicating that $T$. absoluta populations are less likely to be favored when exposed to the lower doses.

The International Organization for Biological Control (IOBC) classifies insecticides in four groups, depending on their toxicity to natural enemies: harmless ( $<30 \%$ mortality), slightly harmful $(30 \%-79 \%$ mortality), moderately harmful ( $80 \%-99 \%$ mortality), and harmful (> 99\% mortality) [47]. Amides 14, 15, and 16 can be classified as harmless to $S$. saevissima, since they caused low mortality rates $(<8 \%)$. Conversely, they were harmful (mortality $>93 \%$ ) toward P. ignobilis according to the IOBC classification. This contrast may be due to the difference in sensitivity at sites of action and/or detoxifying ability, which may vary between organisms [48]. The tolerance of ants of the genus Solenopsis against insecticides has been associated with the activity of the detoxifying enzymes esterases, cytochrome P450 monooxygenases and glutathione S-transferases [49-52]. Natural biological control exerted by predatory species is extremely important in IPM programs, reducing the need for insecticide applications and, consequently, side effects of these molecules [53]. Therefore, the use of the selected amides should be carried out following the principles of ecological selectivity [54], with applications in the late afternoon, when the activity of predatory wasps is lower [55].

\section{Conclusions}

Amides 14, 15, and 16 presented high acute toxicity toward T. absoluta and did not favor weight gain and leaf consumption of the pest under a sublethal dose. They are potential hit compounds for the development of insecticides to manage T. absoluta. However, despite being selective for the predatory 
ant S. saevissima, their use should be carried out under the principles of ecological selectivity to reduce the adverse effects on other non-target organisms.

Supplementary Materials: The following are available online at http://www.mdpi.com/2311-7524/5/4/70/s1.

Author Contributions: Conceptualization, E.A., M.P., and E.P.; Data Acquisition, E.P., E.F., A.R., A.A., and J.F.; Data Analysis, E.P. and E.F.; Resources, E.A. and M.P.; Writing-Original Draft Preparation, E.P., E.F., and A.R.; Writing-Review and Editing, E.A., M.P., and E.F.; Funding Acquisition, E.A., M.P., and E.P.

Funding: This research received no external funding.

Acknowledgments: Financial support was provided by the National Council for Scientific and Technological Development (Conselho Nacional de Desenvolvimento Científico e Tecnológico-CNPq); Coordination of Improvement of Higher Education Personnel (Coordenação de Aperfeiçoamento de Pessoal de Nível Superior-CAPES-Finance Code 001); Minas Gerais State Foundation for Research Aid (Fundação de Amparo à Pesquisa do Estado de Minas Gerais-FAPEMIG), and Rede Mineira de Química (RQ-MG).

Conflicts of Interest: The authors declare no conflict of interest.

\section{References}

1. Miranda, M.M.M.; Picanço, M.; Zanuncio, J.C.; Guedes, R.N.C. Ecological life table of Tuta absoluta (Meyrick) (Lepidoptera: Gelechiidae). Biocontrol Sci. Technol. 1998, 8, 597-606. [CrossRef]

2. Guedes, R.N.C.; Picanço, M.C. The tomato borer Tuta absoluta in South America: Pest status, management and insecticide resistance. EPPO Bull. 2012, 42, 211-216. [CrossRef]

3. Desneux, N.; Luna, M.G.; Guillemaud, T.; Urbaneja, A. The invasive South American tomato pinworm, Tuta absoluta, continues to spread in Afro-Eurasia and beyond: The new threat to tomato world production. J. Pest Sci. 2011, 84, 403-408. [CrossRef]

4. Campos, M.R.; Biondi, A.; Adiga, A.; Guedes, R.N.C.; Desneux, N. From the Western Palaearctic region to beyond: Tuta absoluta 10 years after invading Europe. J. Pest Sci. 2017, 90, 787-796. [CrossRef]

5. Biondi, A.; Guedes, R.N.C.; Wan, F.-H.; Desneux, N. Ecology, worldwide spread, and management of the invasive South American tomato pinworm, Tuta absoluta: Past, present, and future. Annu. Rev. Entomol. 2018, 63, 239-258. [CrossRef]

6. Pfeiffer, D.G.; Muniappan, R.; Sall, D.; Diatta, P.; Diongue, A.; Dieng, E.O. First record of Tuta absoluta (Lepidoptera: Gelechiidae) in Senegal. Florida Entomol. 2013, 96, 661-662. [CrossRef]

7. Brévault, T.; Sylla, S.; Diatte, M.; Bernadas, G.; Diarra, K. Tuta absoluta Meyrick (Lepidoptera: Gelechiidae): A new threat to tomato production in sub-Saharan Africa. Afr. Entomol. 2014, 22, 441-444. [CrossRef]

8. Tropea Garzia, G.; Siscaro, G.; Biondi, A.; Zappalà, L. Tuta absoluta, a South American pest of tomato now in the EPPO region: Biology, distribution and damage. EPPO Bull. 2012, 42, 205-210. [CrossRef]

9. Picanço, M.; Leite, G.L.D.; Guedes, R.N.C.; Silva, E.A. Yield loss in trellised tomato affected by insecticidal sprays and plant spacing. Crop Prot. 1998, 17, 447-452. [CrossRef]

10. Campos, M.R.; Silva, T.B.M.; Silva, W.M.; Silva, J.E.; Siqueira, H.A.A. Spinosyn resistance in the tomato borer Tuta absoluta (Meyrick) (Lepidoptera: Gelechiidae). J. Pest Sci. 2015, 88, 405-412. [CrossRef]

11. Siqueira, H.A.A.; Guedes, R.N.C.; Fragoso, D.B.; Magalhaes, L.C. Abamectin resistance and synergism in Brazilian populations of Tuta absoluta (Meyrick) (Lepidoptera: Gelechiidae). Int. J. Pest Manag. 2001, 47, 247-251. [CrossRef]

12. Roditakis, E.; Vasakis, E.; García-Vidal, L.; Martínez-Aguirre, M.R.; Rison, J.L.; Haxaire-Lutun, M.O.; Nauen, R.; Tsagkarakou, A.; Bielza, P. A four-year survey on insecticide resistance and likelihood of chemical control failure for tomato leaf miner Tuta absoluta in the European/Asian region. J. Pest Sci. 2018, 91, 421-435. [CrossRef]

13. Silva, G.A.; Picanço, M.C.; Bacci, L.; Crespo, A.L.B.; Rosado, J.F.; Guedes, R.N.C. Control failure likelihood and spatial dependence of insecticide resistance in the tomato pinworm, Tuta absoluta. Pest Manag. Sci. 2011, 67, 913-920. [CrossRef]

14. Campos, M.R.; Silva, T.B.; Silva, W.M.; Silva, J.E.; Siqueira, H.A. Susceptibility of Tuta absoluta (Lepidoptera: Gelechiidae) Brazilian populations to ryanodine receptor modulators. Pest Manag. Sci. 2015, 71, 537-544. [CrossRef] [PubMed] 
15. Gontijo, P.C.; Picanço, M.C.; Pereira, E.J.G.; Martins, J.C.; Chediak, M.; Guedes, R.N.C. Spatial and temporal variation in the control failure likelihood of the tomato leaf miner, Tuta absoluta. Ann. Appl. Biol. 2013, 162, 50-59. [CrossRef]

16. Aktar, W.; Sengupta, D.; Chowdhury, A. Impact of pesticides use in agriculture: Their benefits and hazards. Interdiscip. Toxicol. 2009, 2, 1-12. [CrossRef] [PubMed]

17. Chagnon, M.; Kreutzweiser, D.; Mitchell, E.A.D.; Morrissey, C.A.; Noome, D.A.; Van Der Sluijs, J.P. Risks of large-scale use of systemic insecticides to ecosystem functioning and services. Environ. Sci. Pollut. Res. 2015, 22, 119-134. [CrossRef]

18. Cônsoli, F.L.; Parra, J.R.P.; Hassan, S.A. Side-effects of insecticides used in tomato fields on the egg parasitoid Trichogramma pretiosum Riley (Hym., Trichogrammatidae), a natural enemy of Tuta absoluta (Meyrick) (Lep., Gelechiidae). J. Appl. Entomol. 1998, 122, 43-47. [CrossRef]

19. Resende, G.C.; Alvarenga, E.S.; Araújo, T.A.; Campos, J.N.; Picanço, M.C. Toxicity to Diaphania hyalinata, selectivity to non-target species and phytotoxicity of furanones and phthalide analogues. Pest Manag. Sci. 2016, 72, 1772-1777. [CrossRef]

20. Gerwick, B.C.; Sparks, T.C. Natural products for pest control: An analysis of their role, value and future. Pest Manag. Sci. 2014, 70, 1169-1185. [CrossRef]

21. Isman, M.B.; Akhtar, Y. Plant natural products as a source for developing environmentally acceptable insecticides. In Insecticides Design Using Advanced Technologies; Springer: Berlin/Heidelberg, Germany, 2007; pp. 235-248.

22. Tavares, W.S.; Cruz, I.; Petacci, F.; Freitas, S.S.; Serrão, J.E.; Zanuncio, J.C. Insecticide activity of piperine: Toxicity to eggs of Spodoptera frugiperda (Lepidoptera: Noctuidae) and Diatraea saccharalis (Lepidoptera: Pyralidae) and phytotoxicity on several vegetables. J. Med. Plants Res. 2011, 5, 5301-5306.

23. Brito, E.F.; Baldin, E.L.L.; Silva, R.C.M.; Ribeiro, L.P.; Vendramim, J.D. Bioactivity of Piper extracts on Tuta absoluta (Lepidoptera: Gelechiidae) in tomato. Pesqui. Agropecuária Bras. 2015, 50, 196-202. [CrossRef]

24. Paula, V.F.; Barbosa, L.C.A.; Demuner, A.J.; Piló-Veloso, D.; Picanço, M.C. Synthesis and insecticidal activity of new amide derivatives of piperine. Pest Manag. Sci. 2000, 56, 168-174. [CrossRef]

25. Qu, H.; Yu, X.; Zhi, X.; Lv, M.; Xu, H. Natural-product-based insecticidal agents 14. Semisynthesis and insecticidal activity of new piperine-based hydrazone derivatives against Mythimna separata Walker in vivo. Bioorg. Med. Chem. Lett. 2013, 23, 5552-5557. [CrossRef] [PubMed]

26. Ribeiro, T.S.; Lima, L.F.; Previato, J.O.; Previato, L.M.; Heise, N.; Lima, M.E.F. Toxic effects of natural piperine and its derivatives on epimastigotes and amastigotes of Trypanosoma cruzi. Bioorg. Med. Chem. Lett. 2004, 14, 3555-3558. [CrossRef]

27. Aguiar, A.R.; Alvarenga, E.S.; Lopes, M.C.; Santos, I.B.; Galdino, T.V.; Picanço, M.C. Active insecticides for Diaphania hyalinata selective for the natural enemy Solenopsis saevissima. J. Environ. Sci. Health Part B 2016, 51, 579-588. [CrossRef]

28. Farias, E.S.; Silva, E.M.P.; Teixeira, M.G.; Ferreira, J.S.; Alvarenga, E.S.; Picanço, M.C. Phthalides as promising insecticides against Tuta absoluta (Lepidoptera: Gelechiidae). J. Environ. Sci. Health Part B Pestic. Food Contam. Agric. Wastes 2018, 53, 49-56. [CrossRef]

29. Alvarenga, E.S.; Carneiro, V.M.T.; Resende, G.C.; Picanço, M.C.; Farias, E.D.S.; Lopes, M.C. Synthesis and insecticidal activity of an oxabicyclolactone and novel pyrethroids. Molecules 2012, 17, 13989-14001. [CrossRef]

30. Moreira, M.D.; Picanço, M.C.; Barbosa, L.C.A.; Guedes, R.N.C.; Barros, E.C.; Campos, M.R. Compounds from Ageratum conyzoides: Isolation, structural elucidation and insecticidal activity. Pest Manag. Sci. 2007, 63, 615-621. [CrossRef]

31. Jelihovschi, E.; Faria, J.C.; Allaman, I.B. ScottKnott: A package for performing the Scott-Knott clustering algorithm in R. TEMA (São Carlos) 2014, 15, 3-17. [CrossRef]

32. R Core Team. R: A Language and Environment for Statistical Computing; R Foundation for Statistical Computing: Vienna, Austria, 2017.

33. BRASIL. Manual de Protocolo Para Testes de Eficácia de Produtos Desinfestantes; Agência Nacional de Vigilância Sanitária: Brasília, Brazil, 2004.

34. Scott, I.M.; Jensen, H.; Scott, J.G.; Isman, M.B.; Arnason, J.T.; Philogène, B.J.R. Botanical insecticides for controlling agricultural pests: Piperamides and the Colorado potato beetle Leptinotarsa decemlineata Say (Coleoptera: Chrysomelidae). Arch. Insect Biochem. Physiol. 2003, 54, 212-225. [CrossRef] [PubMed] 
35. Duke, S.O.; Cantrell, C.L.; Meepagala, K.M.; Wedge, D.E.; Tabanca, N.; Schrader, K.K. Natural toxins for use in pest management. Toxins 2010, 2, 1943-1962. [CrossRef] [PubMed]

36. Blazka, M. Acute toxicity and eye irritancy. In Principles and Methods of Toxicology, 5th ed.; CRC Press: Boca Raton, FL, USA, 2007; pp. 1131-1177.

37. Rathburn, C.B. Insecticide formulations-Types and uses: A review. J. Am. Mosq. Control Assoc. 1985, 1, 80-84.

38. Elliott, M.; Farnham, A.W.; Janes, N.F.; Johnson, D.M.; Pulman, D.A.; Sawicki, R.M. Insecticidal amides with selective potency against a resistant (Super-kdr) strain of houseflies (Musca domestica L.). Agric. Biol. Chem. 1986, 50, 1347-1349. [CrossRef]

39. Okwute, S.K.; Egharevba, H.O. Piperine-type amides: Review of the chemical and biological characteristics. Int. J. Chem. 2013, 5, 99-122. [CrossRef]

40. Whitehead, S.R.; Bowers, M.D. Chemical ecology of fruit defence: Synergistic and antagonistic interactions among amides from Piper. Funct. Ecol. 2014, 28, 1094-1106. [CrossRef]

41. Scott, I.M.; Jensen, H.R.; Philogène, B.J.R.; Arnason, J.T. A review of Piper spp. (Piperaceae) phytochemistry, insecticidal activity and mode of action. Phytochem. Rev. 2008, 7, 65-75. [CrossRef]

42. van der Werf, H.M.G. Assessing the impact of pesticides on the environment. Agric. Ecosyst. Environ. 1996, 60, 81-96. [CrossRef]

43. Fenner, K.; Canonica, S.; Wackett, L.P.; Elsner, M. Evaluating pesticide degradation in the environment: Blind spots and emerging opportunities. Science 2013, 341, 752-758. [CrossRef]

44. Moriarty, F. The sublethal effects of synthetic insecticides on insects. Biol. Rev. 1969, 44, 321-356. [CrossRef]

45. Wang, D.; Gong, P.; Li, M.; Qiu, X.; Wang, K. Sublethal effects of spinosad on survival, growth and reproduction of Helicoverpa armigera (Lepidoptera: Noctuidae). Pest Manag. Sci. 2009, 65, 223-227. [CrossRef]

46. Janmaat, A.F.; Bergmann, L.; Ericsson, J. Effect of low levels of Bacillus thuringiensis exposure on the growth, food consumption and digestion efficiencies of Trichoplusia ni resistant and susceptible to Bt. J. Invertebr. Pathol. 2014, 119, 32-39. [CrossRef] [PubMed]

47. Sterk, G.; Hassan, S.A.; Baillod, M.; Bakker, F.; Bigler, F.; Blümel, S.; Bogenschütz, H.; Boller, E.; Bromand, B.; Brun, J.; et al. Results of the seventh joint pesticide testing programme carried out by the IOBC/WPRS-Working Group ‘Pesticides and Beneficial Organisms'. BioControl 1999, 44, 99-117. [CrossRef]

48. Tomé, H.V.V.; Ramos, G.S.; Araújo, M.F.; Santana, W.C.; Santos, G.R.; Guedes, R.N.C.; Maciel, C.D.; Newland, P.L.; Oliveira, E.E. Agrochemical synergism imposes higher risk to Neotropical bees than to honeybess. R. Soc. Open Sci. 2017, 4, 1-11. [CrossRef] [PubMed]

49. Valles, S.M.; Perera, O.P.; Strong, C.A. Gene structure and expression of the glutathione S-transferase, SiGSTS1, from the red imported fire ant, Solenopsis invicta. Arch. Insect Biochem. Physiol. 2006, 61, 239-245. [CrossRef] [PubMed]

50. Chen, J.; Rashid, T.; Feng, G. Esterase in imported fire ants, Solenopsis invicta and S. Richteri (Hymenoptera: Formicidae): Activity, kinetics and variation. Sci. Rep. 2014, 4, 1-9. [CrossRef] [PubMed]

51. Zhang, B.; Zhang, L.; Cui, R.; Zeng, X.; Gao, X. Cloning and expression of multiple cytochrome P450 genes: Induction by fipronil $\mathrm{n}$ workers of the red imported fire ant (Solenopsis invicta Buren). PLoS ONE 2016, 11, e0150915. [CrossRef]

52. Araújo, T.A.; Picanço, M.C.; Ferreira, D.O.; Campos, J.N.; Arcanjo, L.P.; Silva, G.A. Toxicity and residual effects of insecticides on Ascia monuste and predator Solenopsis saevissima. Pest Manag. Sci. 2017, 73, 2259-2266. [CrossRef]

53. Gurr, G.M.; Wratten, S.D.; Snyder, W.E. Biodiversity and Insect Pests: Key Issues for Sustainable Management; Gurr, G.M., Wratten, S.D., Snyder, W.E., Read, D.M.Y., Eds.; Wiley-Blackwell: Chichester, UK, 2012.

54. Hull, L.A.; Beers, E.H. Ecological selectivity: Modifying chemical control practices to preserve natural enemies. In Biology Control in Agriculture IPM System; Elsevier: Amsterdam, The Netherlands, 1985; pp. 103-122.

55. Picanço, M.C.; Oliveira, I.R.; Rosado, J.F.; Silva, F.M.; Gontijo, P.C.; Silva, R.S. Natural biological control of Ascia monuste by the social wasp Polybia ignobilis (Hymenoptera: Vespidae). Sociobiology 2010, 56, 67-76.

(C) 2019 by the authors. Licensee MDPI, Basel, Switzerland. This article is an open access article distributed under the terms and conditions of the Creative Commons Attribution (CC BY) license (http://creativecommons.org/licenses/by/4.0/). 